\title{
THE BIBLICAL CREATION ACCOUNTS AND EVOLUTION: A CATHOLIC PERSPECTIVE*
}

Patrick, J. Hartin

Department of Religious Studies. Wits, 1 Jan Smuts Avenue, Johannesburg, 2000

\section{ABSTRACT}

Faith and reason are not two conflicting sources for knowledge. Truth is one, and both faith and reason try to give an understanding of the truth from different perspectives which are not necessarily contradictory. This is illustrated by means of an issue that is often presented as an area of conflict between faith and science, namely creation and evolution. Using the methods of historical criticism, and examination of the biblical creation accounts is undertaken. The purpose is to ascertain the message of these accounts with regard to God and humanity. A further examination is made to see how this message has been understood over the centuries in the context of Roman Catholic tradition. Finally, the attempt will be made to show how an understanding of evolution can be harmonised with what Scripture teaches and the way it has been appropriated over the centuries.

\section{INTRODUCTION}

For a Roman Catholic theologian the adage Scripture and Tradition becomes very real in the debate relating to the biblical accounts of creation. For in examining these accounts the theologian also has to take into consideration the way this teaching has been understood in the course of the church's history. This is obviously an area of vast consideration and it is not possible to treat everything within the confines of a short paper. What $I$ intend to do is to look at two issues: Firstly, as my real field of expertise is biblical scholarship I shall

* This paper was presented at the sixth New Era conference on God: The Contemporary Discussion at Key West. Florida in April 1988. Printed with permission. Koers 54(3) 1989 
examine the biblical accounts to establish their teaching. Secondly, the church's understanding of this teaching will be investigated solely from the viewpoint of evolution. In this latter consideration two particular issues will be treated.

\section{THE TEACHING OF THE BIBLICAL CREATION ACCOUNTS}

The biblical teaching on creation is not a major theme running throughout the Old en New Testaments. In fact when Israel made its earliest professions of faith, a belief in god as creator is noticeably absent (cf. Deut 26:5-10). In the earliest thought of israel the faith in the creation did not have the importance it assumed at a later st. . In the Old Testament its consideration is limited to the opening chapters ; Genesis $(1: 1-2: 4 a: 2: 4 b-25)$ wherein the basic teaching is contained. Wherever references do occur in the rest of the Old Testament, the texts tend to repeat or re-emphasize aspects already contained in these opening chapters (e 9 . Ps 33:6; Prov 3:19-20;8:22). In the New Testament creation is also not emphasized. What tends to happen is that the teaching is placed within a Christological perspective. Paul introduces a new idea into the creation: Christ is the first-born of all creation. As a consequence everything comes into being through him and all things tend towards him (Col $1: 15$ ).

Here attention will be focused on the opening chapters of Genesis as this provides the point of comparison for modern reflections on the harmony between the bible and scientific theories on the origin of the universe. It is important to commence a consideration of Israel's understanding of creation by seeing it against its own worldview and not within the modern setting. For the issues which concern the Genesis accounts are not those of the modern world. What Israelite thought has done is to borrow the concepts of creation from its own world; but in the process it has transformed them and harmonized them within its own worldview. In the accounts of creativn from the ancient near east the world is the outcome of enmity and strife. ng the gods. For example, in the Enuma Elish account (Pritchard, 1969:60, :) from the body of one goddess, Tiamat, the world is created while humanity is fashioned from the blood of another slain god, Kingu. An analysis of these ancient forms of expression of the creation shows that the literary expression of the creation accounts in the book of Genesis owes an immense debt to these extra-biblical sources. One 
can say that the literary bases for the accounts are to be found in extra-biblical sources. At the same time the biblical thought and teaching transcended that to which it was indebted. This transcendence is seen from the very concept of Israel's deity.

\subsection{The literary form of the biblical creation accounts}

To appreciate and understand the creation accounts of Genesis 1-3 one must give attention to their type of writing, their literary genre. They do not claim to be a scientific description of the creation. They do deal with the origins of the world, but they make no pretence to present factual accounts of how the world came into being by describing the actual stages through which all things passed. Neither are they simply a poetical description of the origins of things. On one level one can refer to them as history, in that they deal with an occurrence at the outset of history. However, they are not history as is understood in the modern sense of the word, for they are not the result of memories that have been handed on from generation to generation.

Probably, the best way to describe the literary form of these chapters is to see them simply as religious teaching which concerns, above all, God as the origin of all things that exist. Secondly, their teaching aims at the instruction of humanity by giving an insight into reality which presents one with truths by which one can live. Consequently, the aim is not to speculate on the nature of God and to present a speculative theology. Instead, the aim is practical in that is presents humanity with an insight into the ultimate realities which give meaning to daily life. In this sense it is truly wisdom teaching which offers the individual advice on how to lead his life successfully.

The late Canon Chaine classified the first eleven chapters of Genesis as wisdom literature and in fact the designation of the Pentateuch and the former prophets as 'historical' has been a misleading designation for at least a hundred years. These books are not so much historical narrative as reflections on the human condition, the explanation, as I have called it, of an existing situation by its origins. The narrative literature of Is rael was surely composed not for information but as a guide to decision; from the events of the past and the wise sayings of the elders the 
Is raelite might learn how to meet the present reality. which was still the encounter of Yahiveh with man.

(McKenzie, 196 i:8)

The literary form understood in this manner shows that these writings are not really involved in issues such as evolution, monogenism or polygenism. These are modern problems which are beyond the scope of these writings whose main aim is to provide not a speculative theology on the origin of all things, but a wisdom teaching relevant for the conduct of one's daily life.

\subsection{The major teachings of the creation accounts}

\section{$2.2 .1 \mathrm{God}$}

One can say that the teaching on creation is above all a religious affirmation in the sovereignty of God over all things. Israel s belief in God arose from her experience of God within her history over the course of many centuries. In this perspective God is the God of salvation. Now in the context of creation God is presented no longer in relation to one nation, but he is seen as the God of all things and of all men. This confession means that he is Lord of all things. Nothing should be glorified in the world of creation - God alone is the one to whom all glory and worship belong (Ps 24:1-2;89:11-12).

When describing the actual creation, the Genesis narrative presents the picture of making order out of chaos. This is not to be understood as though God fashioned the world out of pre-existing material. The chaos in no way determines God as was the case with the Babylonian creation accounts of Enuma Elish wherein the gods are created from the actual waters of chaos. Although the notion of creation out of nothing (creation ex nihilo) was probably too speculative for the Hebrew mind, nevertheless the aim of the entire narrative is to emphasize that God completely transcends this world and that everything in existence owes its origin to him.

\subsubsection{Humanity}

Both creation accounts ( $\mathrm{G}$ 1:1-2:4a; $2: 4 b-25$ ) attributed to humanity a place of special honour in God's creation. The first creation account ( $\mathrm{Gn} 1: 1-2: 4 \mathrm{a}$ ) 
shows how humanity is the end and climax of alt the God has hitherto created. whereas the second creation account $(2: 1 b-25)$ emphasizes the very special role God plays in creating humanity.

(a) In the fist creation account the stress is placed upon man who is made in the Image and likeness of God $\left(G_{n} 1: 26\right)$. This is something not said in any of God's other creations. The Hebrew word for image (selem) means a copy or reproduction. But, in what way is man a reproduction of God? The answer to this lies in examining the account more closely.

(i) God speaks to humanity directly. whereas this never takes place with any of God's other creation.

(ii) Humanity rules over the world, as Gods replesentative (Gn $1: 28$ ).

(iii) In Genesis 9:6 the special evil of homicide is deduced from the fact that humanity is made in God's image.

From this one concludes that the image of God which humanity possesses and makes them different from the rest of the creation does not mean that they in some way look like God physically. Rather, it must be seen as a quality which they possess, which enables them to enter into a special relationship with God, Into a dialogue with God. As a result of this, humanity possesses this ability to determine itself and its world. With this ability they are given the task of ruling over this world, over God's creation, on behalf of God.

As a result of sin (the fall which is narrated in Genesis 3) this image of God is not destroyed entirely but it is is impaired. Humanity is not capable of entering into a perfect dialogue with God, nor are they capable of ruling this world as God's representative should. Consequently, the person of Christ came to restore the image of God in humanity to what it should be. Through sharing in the image of the Son, the Christian is changed to the image of the creator, to the image which was once possessed at the beginning when God created humanity. This is what Paul means when he says to his Christian readers: Put on the new nature, which is being renewed in knowledge after the image of its creator' (Col 3:10). 
(b) The second creation account stresses again the position withın creation of humanity seen once more as the peak of Gods creation. Attention is given to the special creation of both man and woman, a description which is not given to the rest of creation. Man and woman are seen as equal, as complementing each other. Woman is specially created as man was and she is made from man himself which shows that she has the same nature as man. This idea of man and woman as having the same basic nature is seen from their names in Hebrew (man=IS and woman=ISSAH).

(c) In the story of the fall ( $G n 3: 1-24)$ a teaching is presented by means of accounts of the fall common at that time, such as the Babylonian Adapa Myth'. The biblical account emphasizes that sin is a rebellion against God, against the one God who created the world. It shows, too, that human nature has been changed radically so that one cannot free oneself from one's own situation, and constantly rebels against God. An important aspect in this account is the hope presented to man for the future $(G \cap 3: 15)$. God has promised that he will send someone in the future to free humanity from this situation. He will conquer and destroy the power of evil which exercises such a power over the world.

\subsubsection{Salvation history}

This activity of God in the opening pages of the bible forms part of the wider context of God's dealings with humanity. The bible does not attempt to explain the origin of all things in a scientific or even pre-scientific way. Rather, it presents the starting point in a long process of God's dealings with humanity. Because of $\sin$ and the rejection of God, one can say that chaos threatens to overtake and destroy the creation. The one conviction that emerges is that the creator is always active in the process and offers hope for the ultimate salvation of humanity. God's creative action is to be seen as the beginning of his salvific activity. It is the background and the setting within which God's saving activity takes place.

\section{EVOLUTION AND THE Biblical NARRATIVES}

In the Pastoral Constitution on the Church in the Modern World (Gaudium et Spes) Vatican II emphasized that there are two sources for knowledge. faith and reason (Gaudium et Spes 15). No conflict should be seen to exist between 
them: in fact, each is trying to give an understanding of the truth, and as truth is one, the realms or science and faith cannot teach contradictory things. The constitution criticizes the attitude often found among Christians, namely that the rightful domain of science is not respected (Gaudium et Seps 36). Respect for each domain should be the premise in any attempt for a reconciliation between the biblical perspective on creation and the scientific perspective as illustrated in the theory of evolution. The truth content of each is to be respected and the serious attempt is to be made to bring the two insights together

In the course of the centuries the Catholic Church has re-appropriated the teaching of the Scriptures and has expressed its understanding of this teaching for the period of its own time, drawing attention to certain aspects which are seen to be essential to profess a Catholic faith. It is, however, oniy in more recent times that the question of evolution has been the subject of consideration. In more recent times the Church has urged those experienced in both fields, namely that of theology and that of science. to give their attention to the issues arising from the theory of evolution (DS 3896). There are obviausly many issues that one can and should examine, but I should like to briefly consider two particular questions regarding hominization.

\subsection{The relation between soul and body}

When one speaks about human evolution, it must be understood in terms of organic evolution and this is a typically modern question. Almost from the outset in the discussion on the origin of humanity, an important distinction was drawn between what one might term a biological person and the psycho-social aspect of the person. In traditional religious terms these aspects are referred to as body and soul, whereby the person is viewed as a composition of matter and spirit, of body and soul.

When viewing the teaching of the Scriptures on the creation of humanity, at first sight the theory of evolution seemed to be in contradiction to it. However, as has been noted, the teaching of Genesis is not concerned with presenting the how regarding the creation of humanity, but rather with presenting the fact that God, as creator was responsible for the creation of humanity in a way which was unique with regard to the rest of the creation. In this framework 
the harmonization between the Scriptural teaching and evolution can be seen to emerge from the understanding that humanity both evolved and was created.

The more traditional approach towards the harmonization of evolution arid creation would emphasize the distinction between the person's biological and spiritual aspects as of great importance. Intelligence and free choice distinguish humanity from other primates and from the rest of the material world. In this regard one would see the evolution of the body taking place according to the natural development of the process of evolution, which one would see to be under the all-encompassing providence of the creator. The theory of the evolution of nature and material being does not detract from the glory and power of the creator. In fact, it enhances it. However, the origin of the spiritual faculties of a person is seen to requile a special creative act taking place at the same time as the development of the evolved human body. This creative act would be seen to be beyond the laws of biological evolution. The animal origins of humanity would be placed within the natural process as indicated by biological evolution. At the same time a person's spiritual activities are seen to have emerged from a spiritual principle, not itself the result of biological evolution, but as part of a created and infused act of God, elevating what was formally a hominid to the status of a new species, namely humanity. In this sense then creation and evolution go hand in hand.

A more challenging and modern attempt to express this same teaching is offered by Rahner (1969:296-297). He speaks of God supporting the creature throughout its process of becoming. Every form of becoming is in fact an act of rising beyond itself. In this sense God enables the creature to come to full self-devolopment and self-transcendence, God, as the transcendent cause of all, is the one who makes self-transcendence possible, whereby something new emerges when the being transcends itself. For Rahner matter does have an affinity with spirit because its origin is from the creator, God, who is the absolute spirit $(1969: 296)$. The whole universe is seen to be drawn to that unique goal whereby created matter is drawn by God towards the attainment of created spirit $(1969: 296)$. Consequently, hominization is the culmination of the process of evolution whereby God enables the creature to transcend itself and to become created spirit. In humanity occurs the origin of the universe as well as its finai end $(1969: 296)$. Something new emerges in this process of God s enabling the creature to transcend itself, and in this sense it is referred 
to as creation and is called a direct creation according to more traditional philosophy. In this sense evolution and creation go hand in hand. The traditional teaching has been preserved, but it is made more at harnony with the notion of evolution. In fact, evolution is given a greater glory by drawing it together with God's transcendent creative power working in it.

\subsection{The $\sin$ of Adam}

In the traditional Christian concept of the beginning of humanity, the picture is painted of a state of paradise. This largely conforms to the biblical story that is narrated. Humanity is presented as living in a state of perfection, which is subsequently lost by $\sin$, and finally is progressively restored by Christ. From the perspective of science such a perspective is untenable The picture presented by evolution is that of a gradual upward development in which humanity is evolving towards stages that are always more perfect. The concept of a fall from perfection to inperfection is something hard to reconcile with a picture of the scientific evolution of man.

Many attempts to deal with this question have been undertaken. This is one of the major criticisms levelled against Tellhard de Chardin (1959) who finds it difficult to incorporate the concept of both original sin and the redemption into his concept of organic evolution. What is essential in the revelation of the Scriptures is that the first parents were called to live in grace with God forever. Yet, they fell from or rejected this supernatural life with God. Consequently, it was necessary for God to work redemption through the sending of his Son. In explaining this fall from grace the Christin tradition has spoken about preternatural gifts that humanity possessed and which were lost with the fall, such as the freedom from death and freedom from suffering, etc. But, this has difficulties in being incorporated into a perspective of evolution. To solve the problem a number of theologians have presented the proposal that these preternatural gifts, or this state of paradise, was in fact a promise offered to the first parents which would become operative if they co-operated with God's grace. But they rejected it, and hence these promises never materialized (Metz, 1967: 144ff).

This is also Rahner's perspective (Overhage \& Rahner, 1961:84-90)). He speaks about Adam making a fundamental option against God in which he refused to 
accept God as the norm for his life. Instead, he opted for himself. Not all the gifts were possessed by Adam. He possessed those that were necessary for him to be able to make a choice in freedom (such as grace, and the gift of integrity). Other gifts however (such as freedom trom suffering, etc.) were present only as a gift, as offered to humanity insofar as Adam would have possessed them if he had accepted his submission to God. These gifts offered to him were part of the historical situation of the first human person beginning a moral life, but in no way did they actually form part of the observable phenomena.

This hypothesis has many advantages. It helps one to understand the situation of Adam phenomenologically in an identical way to that which is presented by evolution with regard to the picture of the first human person. In this perspective, on the one hand, the sin of Adam did not demand an anthropological fall, nor even an intellectual fall from perfection to imperfection. On the other hand, the sin committed by Adam is seen to be a very real sin in that it was made with the fullness of clarity given by the gift of integrity, and in its rejection of God it resulted in the loss of the relationship and friendship with God. Again the traditional teaching is preserved here, insofar as humanity's present situation is derived from this first sin of total rejection of God whereby concupiscence, suffering, physical death etc. are all derived from this initial rejection of God. At the same time, these thoughts are presented within a new perspective which was not part of the problematic of previous centuries, be that of the biblical world or the world of the church's magisterium. In this new perspective of evolution the traditional teaching is still preserved. But it is now placed in this wider framework of an evolutionary development by which gifts, promises, or potentialities for actualization are offered to humanity by God. They would not have heen rejected if they had accepted God totally as working in the life of humanity. But, instead, God was rejected. Again evolution and creation are in harmony working together to emphasize the responsibility humanity must bear for its present situation by which they stand in need of God's grace and transcendent power to raise them from the situation of powerlessness through the transforming power of the Redeemer, Jesus Christ. 


\section{CONCLUSION}

Many other issues do present themselves in the harmonization of the concept of creation (as emerges from the sources of the Christian faith, namely the bible and the church's tradition) with that of the theory of evolution. Two examples have been given of how difficulties can be reconciled, very often by rethinking the perspectives and trying to discover the message presented by the biblical writings or church statements. This is done by separating the inessage from the way in which it is presented within the time-bound concepts of its own world view.

At the same time one must not loss sight of the fact that the theory of evolution is a modern perspective and is a concept expressed in modern categories. In harmonizing creation and evolution one is attempting first and foremost to present the Christian teaching within the perspective of twentieth century thought categories. What one is in fact doing is to draw out the message which has been inculturated within a particular world view of centuries ago. while at the same time re-inserting the message within the cultural perspective of the twentieth century. This is valid only insofar as one does not distort the message in the process. By no means is this an easy task, but it should not be avoided for the human person is a thinking being who lives not in two worlds, one of religion, and one of science, but in one world in which there can be but one truth. As there is but one truth, the truths as they appear to us both from religion and from science must be capable of being reconciled. This is the challenge presented today both to the theologian as well as to the scientist, as Vatican 11 indicated so well throughout its Pastoral Constitution on the Church in the Modern World (Gauduim et Spes)

\section{WORKS CONSULTED}

ABBOTT, W., ed. 1966. The Documents of Vatican II. New York: Guild Press.

DARLAP, A., ed. 1969. Sacramentum Mundi. New York: Herder \& Herder, vol. 1-4. 
DARWIN, C. 1957. The origin of species. New York: New American Library.

DARWIN, C. 1969. Autobiography. New York: W.W. Nolton.

DENZINGER, H. \& SCHONMETZER, A. 1972. Enchıridion Symbolorum. Freiburg : Herder.

FICK. M. \& ALSZEGHY, Z. 1964. II Creatore. Rome: Libreria Editrice Fiorentina.

FRAINE, J. DE. 1962. The Bible and the origin of inan. New York: Desclee.

HAYES, Z. 1980. What are they saying about creation? Ramsey: Paulist Press.

HESSLER, B. 1960). The Bible in the light of modern science. Chicago Franciscan Herald.

HULSBOSCH, A. 1965. God in creation and evolution. New York: Sheed $\varepsilon$ Ward.

KRAMER, W. 1986. Evolution $\&$ Creation: a Catholic understanding. Huntington : Our Sunday Visitor.

MCKENZIE, J.L. 1967. Reflections on Wisdom. Journal of Biblical Literature, 86, 1-9.

METZ, J., ed. 1967. The evolving world and theology. Ramsey : Paulist Press.

NEW CATHOLIC ENCYLOPEDIA. 1967. Washington: Catholic University of America .

NOGAR, R. 1963. The wisdom of evolution. Garden City : Doubleday. 
ONG, W., ed. 1960. Darwin's Visıon and Christian perspective. New York Mackillan.

OVERHAGE. P. \& RAHNER, h. 1961. Das Problem der Hominisation. Ouaestiones disputatae, 12-13. Freiburg: Herder.

POPE LEO XIIIl. 1893. Encyclical: Providentissimus Deus.

POPE. PIUS XII. 1913. Encyclical: Divino Aftlante Spiritu.

POPE Pllus $x / 1$ 1950. Encyclical: Humani Generis.

POPPER, K. 1963. Conjectures and refutations. London: Routledge $\varepsilon$ Kegan Paul.

PRITCHARD. J. 1969. Ancient Near Eastern Texts. Princeton: Princeton University Press.

RAHNER, K. 1954. Schriften zum Theologie, 1. Zürich: Benziger.

RAHNER, K 1965. Hominization. New York: Herder \& Herder.

RAHNER, K. 1969. Evolution: II Theological. IIn Darlap, A., ed. Sacramentuin Mundi. New York: Herder \& Herder. p. 289-297.)

TIELHARD DE CHARDIN, P. 1959. The Phenomenon of man. New York Harper \& Brothers

VAWTER, B. 1956. A path through Genesis. New York: Sheed \& Ward. 